\title{
The left-right dimension in the minds of Icelandic voters 1987-2009
}

\author{
Hulda Pórisdóttir, Dr., Assistant Professor of Political Science, \\ University of Iceland ${ }^{1}$
}

\begin{abstract}
The left-right political dimension represents a powerful and parsimonious way to describe political ideology. The right is usually seen as standing for tradition and acceptance of inequality, whereas the left advocates progress and economic redistribution. This study reports an analysis of the left-right scale in the minds of Icelandic voters, using data from the Icelandic National Election Studies from 1987-2009. Findings indicate that the vast majority of respondents are willing to place themselves on the left-right scale, and that they have become increasingly willing to do so since 1987. The average political orientation of Icelanders has consistently been just right of centre, with a moderate dip in 2009. The possibility of political polarization and sorting is considered, and ultimately rejected, based on analyses of the distribution of left-right scores for the entire sample and for subgroups defined by political party affiliation and demographics. Lastly, the contextual nature of the left-right dimension is examined by looking at the relationship over time between attitudes towards six political issues and left-right self-placement. The overarching picture that emerges from this study is that of a stable, well-defined left-right political landscape in the minds of Icelandic voters.
\end{abstract}

Keywords: Political orientation, left-right dimension, Icelandic National Election Studies Introduction.

\section{Introduction}

It has been popular for several decades to declare its irrelevance or outright death (Converse, 1964; Lipset, 1960; Giddens, 1994). Still, the left-right political dimension refuses to go away. This paper reports a study of the left-right dimension among Icelandic voters by using the Icelandic National Election Studies (INES) from 1987 until 2009. The paper commences with a brief history of the left-right dimension, followed by a description of what are believed to be its core components, and a discussion of the psychology of political orientation. After succinctly outlining the Icelandic political landscape, I will address common criticisms and active debates concerning the left-right label. This will be followed by the introduction of five research questions about the use, distribution, and potential polarization of the left-right 
dimension in the Icelandic electorate. It will be noted from the outset that this study will not assess the validity, coherence, or content of the left-right axis among Icelandic voters, a worthy topic but extensive enough to warrant several studies of its own.

\section{The history of the left-right dimension}

The left-right distinction can be traced to the seating arrangements in the French Assembly following the revolution of 1789 . After initial chaos in the new assembly, its members gradually arranged themselves within the chamber in such a way that those loyal to the king and advocates of gradual social change sat to the king's right, whereas more ardent promoters of liberty and equality sat on his left (Noël \& Thérien, 2008). Until the beginning the $20^{\text {th }}$ century, the distinction between left and right did not extend much beyond the French Assembly. Gradually, however, in Europe the term "left" came to stand for those who wanted radical democratic improvements, and later, with socialism, radical redistribution. The "right" was then applied to those who opposed such changes (Adams, 2001). Until the 1970s, the leftright distinction was primarily linked to social class and the workers' struggle. That changed when young and educated people in the West started to reject traditionalism and call for societal changes, primarily in the form of increased economic and social equality for all (Noël \& Thérien, 2008).

Due to its historical roots, the left-right cleavage is sometimes equated with liberalism-conservatism. In the United States, for example, the left-right labels are customarily replaced by the liberalism-conservatism labels (Jost, Glaser, Kruglanski, \& Sulloway, 2003). Those on the right tend to believe in the wisdom of the ages and that social changes should happen slowly. The right-winger is likely to believe that there are good reasons for society to have evolved in the way it has, and that novel ideas should be viewed with scepticism until time has proved them to have merit. G. K. Chesterton phrased this idea memorably as follows: "The whole modern world has divided itself into Conservatives and Progressives. The business of Progressives is to go on making mistakes. The business of the Conservatives is to prevent the mistakes from being corrected." The right is also associated with believing in the importance of authorities and rule following (e.g., Burke, 1790/1999). As a general rule, people on the right are more likely to support the prevailing social order (Jost et al., 2003a, 2003b; Kirk, 1982; Muller, 2001; Wilson, 1973). As capitalism, with its inevitable economic inequality, became in many ways the prevailing social order in the West after the Industrial Revolution, those on the right tended to defend it. The right-wing support for capitalism and the free market was, however, not universal as some felt it represented a radically changed social order and continued to support more traditional societal arrangements. This friction within the right-wing camp has continued to this day with the current separation into economic and social conservatism (Lipset, 1981; Muller, 1997) causing some uneasy alliances within the same political party. Meanwhile, people who wanted redistribution of wealth and more active involvement of the state to guarantee the welfare of its citizens became associated with the left.

As a result of these historical developments, today the left-right dimension is often 


\section{Hulda Pórisdóttir}

\section{STJÓRNSÝSLA}

assumed to consist of opposing attitudes towards resistance to change on one hand and acceptance of inequality on the other (Bobbio, 1996; Huntington, 1957; Kerlinger, 1984; Jost, Glaser, Kruglanski \& Sulloway, 2003a; Muller, 2001). In the American Heritage Dictionary of the English Language conservatism is defined as "a political philosophy or attitude emphasizing respect for traditional institutions, distrust of government activism, and opposition to sudden change in the established order" (Pickett, 2000). Resistance to change embodies the belief described above that ideas are considered worthy of implementation if they stand the test of time and are gradually adopted by societies without radical overhauls or changes (Jost et al., 2003a, 2003b; Kirk, 1982; Muller, 2001; Wilson, 1973). An example of this comes from Edmund Burke (1790/1999) who strongly opposed the French Revolution because he did not see it as a fight for justice and democracy but rather as a rebellion against legitimate authorities and a forced societal change that was bound to end in disaster. Defining resistance to change as a core component of the right has been criticized on the ground that those on the right often advocate radical social change in terms of reduction of government and decreased redistribution (e.g. Greenberg \& Jonas, 2003). Libertarians, a small but significant group of voters, fall into this category, thus representing the uneasy alliance between two strands of conservatism described above. Resistance to change has, however, been included in most definitions of the right since the inception of the terms (for an overview see Jost, Glaser, Kruglanski, \& Sulloway $2003 \mathrm{a}$ and 2003b). Proponents of including resistance to change have argued that the change advocated by those on the right is usually in reference to some version of a "retroactive change to an idealized past", whether this represents a purer version of capitalism, religious morals or something else (Jost, Glaser, Kruglanski, \& Sulloway, 2003b).

The other major dividing line between left and right stands for attitudes towards inequality, both in terms of individual abilities (or inputs) and economic resources (or outcomes; see Bobbio, 1996; Giddens, 1994; Jost et al., 2003a; 2003b, Jost, 2006; Kirk, 1982; Muller, 2001). The right stands for the belief that inequality is unavoidable, and perhaps even desirable; unavoidable because there will always be natural differences in peoples' abilities and motives that no governmental policies will be able to fix. Inequality could be desirable for two reasons. First, because it encourages people to aim higher and strive harder. Second, because a social system designed to eliminate naturally occurring inequality will create an even worse state of affairs to the extent that it will have been artificially forced into existence by politicians.

\section{The psychology of left and right}

Extensive research within political psychology has helped validate the soundness of the left-right dimension. This research has focused on the different attitudes, goals, values, motives, and personalities of adherents of left- versus right-wing ideology. In a metaanalysis of 88 studies on this topic covering more than 50 years of research, Jost, Glaser, Kruglanski and Sulloway (2003a) found that both dispositional and situational variables associated with management of threat and uncertainty were reliably related to left-right political orientation. Specifically, they found that intolerance of ambiguity, need for structure and closure, even death anxiety and fear of threat and loss were all positively 
related to right-wing political leanings. Openness to new experiences, tolerance of uncertainty, and preference for cognitive complexity were, on the other hand, negatively related to right-wing attitudes. Jost and colleagues have since termed this set of psychological traits "elective affinities", indicating that people with certain psychological needs, whether situationally or dispositionally derived, will be drawn to either left or right ideology in order to meet those needs (Jost, Federico, \& Napier, 2009).

\section{The Icelandic left and right}

In Icelandic politics the terms left, right, and centre are frequently used by both political elites and the general public to describe the political stance of parties, politicians, and policies. The political scene has been dominated by more or less the same four large political parties since the 1930s. Although there have been some mergers and separations during this time, with temporary fifth or sixth parties, the four-party pattern has continued to re-emerge (Kristinsson, 2007). The left-right stance of these parties is generally undisputed. The right wing has been mostly united in the Independence Party since its foundation in 1929. The left has been more fractioned, with parties coming and going. Today, however, the Left-Green Movement furthest to the left, and the pro-EU Social Democratic Alliance closer to the middle, in most ways echo their older counterparts with different names, the People's Alliance and the Social Democratic Party respectively. The Progressive Party, a former farmer's party, is a relatively small centre party, albeit with substantial political clout due to its ability to form coalition governments with both left and right-wing parties. Typically, the Independence Party is largest, receiving around 35\% of the national vote, followed by the Social Democratic Alliance with around 25-30\%, with the Left-Greens and the Progressive Party each receiving 10-20\% (Statistics Iceland, n.d.).

A recent $\mathrm{BA}$ study dissertation at the University of Iceland took on an ambitious study of political ideology among Icelanders (Valgarðsson, 2012). In this study, a large convenience sample of people was asked about their stated ideology, their opinion on a multitude of political statements, and how they would place those same statements on the left-right scale. Analysis showed a high level of agreement in the way participants placed political statements on the left-right dimensions (or whether they thought the statements did not separate left from right). There was similarly high consistency in opinions, such that participants who had a left-wing opinion on a particular issue were more likely to have a left-wing opinion on other issues as well. Results furthermore indicated that the left-right dimension in Icelandic politics is primarily determined by attitudes towards capitalism and economic redistribution. Social issues, on the other hand, play a negligent role in determining the left-right stance. From a psychological standpoint a final interesting finding of this study is that attitudes towards resistance to change did not emerge as an important dividing line in Icelandic politics. It is hard to tell whether this is an accurate depiction of the political landscape, or whether it is attributable either to the sample being somewhat younger, more educated, and more interested in politics than the general population, or to a methodological flaw in which questions that would truly tap into resistance to change were missing from the survey. 


\section{Critique of the left-right dimension}

Although nobody who studies, observes, or participates in politics in the West can reasonably reject the existence of a left-right political dimension, it has not been without criticism. The most common objection is probably that it is too simple to be meaningful. According to this critique, the left-right dimension lumps together opinions that do not have a logical connection, such as opinions on taxes and religion. Because of this, the left-right dimension is said not only to obscure other important differences and similarities in political leanings that do not fall under its definitions (Conover \& Feldman, 1981; Kerlinger, 1984), but create artificial opinion barriers between people and parties (Brittan, 2012).

Another critique of the left-right label is that although it used to have a meaning during the extreme political atmosphere of World War II and the Cold War, it has for the most part lost its meaning. Modern-day politics, at least in the West, have assimilated left and right ideas into current combinations of capitalism and state-run safety-nets and services (Bell, 1960; Giddens, 1998, Lipset, 1960). This was one of the claims made during the "end of ideology" debate initiated by Converse (1964). That debate also focused on the role of political elites and the lack of sophistication of the public. Converse and others claimed that members of the political elite created ideological packages they then handed down to the public who accepted them without fully, or even partially, understanding the content of the ideological package they had adopted as their own (Converse, 1964; Feldman, 1988, 2003; Fiorina, 2005; Kinder, 1988).

Proponents of the left-right distinction have responded to this criticism by saying that although it is true that the dimension is too simple to capture all nuances in political differences, it is the most powerful and parsimonious way we have of classifying political attitudes (Feldman, 2003; Fuchs and Klingemann, 1990; Jost, 2006; Knight, 1999; Noël \& Thérien, 2008). This is reflected not only by the fact that the left-right language is ubiquitous in all political discourse (e.g., Jennings, 1992; McCarty, Poole \& Rosenthal, 2007) but also by people's willingness to place themselves on the left-right scale when prompted. Noël and Thérien (2008) reported a summary from the World Values Survey (WVS), a large international survey project covering close to eighty societies. They found that only $22.4 \%$ of people worldwide refused to place themselves on the scale, the residents of former communist countries in Eastern Europe being among the least likely to do so.

In Noël and Thérien's summary of the WVS from 1999-2001, only 9.5\% of Icelanders said they did not know, or refused to answer, when asked to place themselves on the left-right scale. Although this number indicates that the left-right scale has a meaning in the minds of Icelanders, we do not know if it has been increasing or decreasing over time. The first research question to be addressed in these analyses is, therefore, the following:

Q1: Has the number of Icelandic voters willing to place themselves on the left-right scale changed over time? 
People's willingness to use the left-right scale could mask another way in which the scale has lost meaning. As was discussed above, several studies have maintained that the extremities of left and right belong to the past and that politics has met in the middle. If this is true, we would expect to see a change in the way Icelanders use the left-right scale. Specifically, the number of people placing themselves in the middle could be expected to have risen. If, on the other hand, the left-right dimension represents an enduring political cleavage, such clustering around the mean has not taken place. The second research question is therefore:

Q2: Has the number of participants selecting the middle option remained stable increased over time?

\section{Political Polarization}

In stark contrast to the contention that the distinction into left and right is meaningless, or has given way to an all-encompassing centre, is the idea that the electorate has become more polarized in recent decades. This has primarily been discussed in the United States. Most agree that polarization has taken place at the political elite level in the US, such as in Congress and in the media (Fiorina \& Abrams, 2008). A lively debate, however, has taken place among scholars on whether there truly has been a polarization among the general electorate. One reason for the liveliness of the polarization debate stems from a lack of conceptual clarity. Different scholars, and different areas of study, mean different things by "polarization".

Abramowitz and colleagues argue for real polarization (Abramowitz \& Saunders, 2005; Abramowitz \& Saunders, 2008). They have analyzed the National Election Studies over time and show evidence for an electorate becoming more consistently liberal or conservative on issues, and that this tendency is more pronounced for people with a high level of knowledge and interest in politics. According to these authors, partisan polarization has also increased, as is evident from a rising correlation between left-right self-placement and identification with either the Democratic or Republican Party. In addition, geographical and religious polarization has also been on the rise, as seen by states in the United States becoming solidly either so call red states or blue states, and by the strong alignment between religiosity and conservatism (Abramowitz \& Saunders, 2008).

Fiorina and colleagues disagree with these conclusions and argue that it is important to differentiate between polarization and sorting. Polarization means a genuine increase in the distribution of opinions in which fewer people share a middle ground. Sorting on the other hand refers to subgroups within the larger distribution (based on partisanship, geography, religion etc.) aligning themselves closer with ideological or partisan labels. Fiorina argues that research unequivocally points to sorting but that real polarization on political opinions has not been taking place among the American public (Fiorina \& Abrams, 2008). Mason (2012) claims the debate on polarization is muddled by conceptual confusion. She stresses the importance of distinguishing between issue position polarization, as evident by increasingly extreme opinions on political issues, and behavioural polarization which is increased party allegiance and 
emotional attachment to political labels, without the underlying issue position polarization.

No research exists on whether polarization or sorting, has been on the rise among the Icelandic public. The media paints a picture of Althingi as increasingly divided, that while in the good old days parliamentarians used to share both lunches and issue stances across parties; not any more (Hjörvar, 2012; Pressan.is, 2012; Stephensen, 2012;). In general, however, it is probably safe to say that there is no general impression that Icelanders have become more ideologically divided over the last 25 years or so. Potential polarization and sorting will be assessed with the following questions:

Q3a: Has the distribution of left-right placement increased over time, thus indicating increased real polarization on the left-right dimension within the Icelandic electorate?

Q3b: Has political sorting taken place in the Icelandic electorate, such that subgroups based on political party affiliation or demographic variables align themselves more closely with either the left or the right?

\section{False Polarization}

Even if no real polarization has taken place among Icelandic voters, this does not rule out the existence of perceived polarization. Perceived polarization is when voters perceive parties or people to have been shifting further away from the middle, even if attitude measurements indicate no such shifts. The tendency to overestimate the extremity of a political opponent's views can be viewed in the context of the false polarization effect (Dimdins and Montgomery, 2003). A study by Robinson, Keltner, Ward and Ross (1995) showed that respondents who labelled themselves as either pro-life or pro-choice on abortion, in actuality ranked closer to each other on the issue than they themselves presumed. More generally, both partisans and non-partisans tend to overestimate the polarization of partisans' views. In addition, what exacerbates the false polarization effect is that people are prone to believe that their own ideas are more in the middle than others' ideas. The tendency is to attribute the attitudes and behaviours of others to the ideological stance of the group they belong to, but to see one's own behaviour as driven more by independent thought and less by group ideas and conformity. Thus, people are likely to realize that other people's inferences are biased but have difficulty seeing the effects of the same biases on their own attitudes and behaviour (Pronin, 2007). As a result, even if voters for all parties have remained more or less stable in their ideological placement on the left-right scale across time, at least two indicators of false polarization may be evident and will be examined:

Q4a: Do we see perceived polarization among the Icelandic public in the sense that even if no real polarization has taken place, people perceive other parties as having moved more towards the extremes over time? 
Q4b: Is there evidence of false polarization among Icelandic voters such that voters estimate the political stance of opposing parties as being closer to the extreme than it is according to their own voters?

\section{Contextuality of the left-right dimension}

No matter how useful and meaningful the left-right dimension is for classifying political opinions, it is a socially constructed idea and as such bound to be context dependent. It may mean different things in different cultures and take on different meanings across time (Noël \& Thérien, 2008). We know, for example, that in Israel the left-right distinction revolves almost exclusively around stances on the conflict with Palestine (Opp, Finkel, Muller, Wolfsfeld, Dietz, \& Green, 1995). In Eastern Europe, resistance to change is to some degree linked with the old Communist order (Thorisdottir, Jost, Liviatan, and Jost, 2007) and in South America the meaning of "left" is primarily linked with some version of populism (Noël \& Thérien, 2008). This has sometimes been seen as a weakness of the construct and a sign of its arbitrariness (Greenberg \& Jonas, 2003). Jost and colleagues (2003a, 2003b) discussed this malleability of the left-right dimension by noting that although the specific content of political issues may vary across time, the underlying tensions between tradition versus progress, and between equality versus inequality, can almost always be identified in democratic societies.

'The two final questions to be addressed in this study examine the stability of attitudes on particular political issues across time. Although this inquiry is going to be somewhat limited by the low number of questions consistently asked since 1987, it will allow for some insight into the stability of political attitudes across time. Specifically, on the six issues of taxes, environmental protection, NATO membership, prosperity of urban vs. rural areas, restrictions on agricultural imports, an EU application, and gender equality, an analysis will be made to establish whether the entire electorate has moved either to the left or the right across time. If we see consistent shifts in attitudes towards political issues without corresponding changes in people's self-placement on the overall left-right dimension, this will lend support to the relativity argument of the left-right dimension. Finally, an examination of attitudes towards these six political issues across time will provide for another opportunity to test for polarization, i.e. whether the correlation between left-right placement and these attitudes has grown stronger over time. The final two questions to be answered in this study are the following:

Q5a: Have attitudes towards taxes, environmental protection, NATO membership, prosperity of urban vs. rural areas, restrictions on agricultural imports, an EU application, and gender equality remained stable over time, or has there been a shift either to the left or the right?

Q5b: Has the correlation between left-right self-placement and these political issues grown stronger over time, thus indicating polarization among the Icelandic electorate? 


\section{Method}

The Icelandic National Election Study (INES) has been conducted following every parliamentary election since 1983 (Harðarson, e. d.). As a rule, parliamentary elections are held every four years. In 2009 elections were held two years prematurely due to political turmoil following the economic crisis in the fall of 2008 and the subsequent downfall of the government. INES is a wide-ranging phone survey covering topics such as voting behaviour, attitudes towards political issues of the day, people's perceptions of the state of democracy, and several demographic variables. The survey has always been conducted by nationally recognized survey companies using a nationally representative sample drawn from the Icelandic national registry. The number of responses has ranged from 1,385 to 1,745. INES is one of several international collaborations on national elections studies, including the Nordic Electoral Democracy, Comparative Studies of Electoral Systems, and True European Voter.

Participants were asked several questions about political orientation, both their own and that of the political parties, according to their perception. The questions were as follows: 1) "Where would you place yourself on a scale from 0 - 10 , where 0 is left and 10 is right?" 2) "Where would you place [PARTY] on a scale from 0 - 10, where 0 is left and 10 is right?" Participants were asked to place all parties that had representatives elected to the parliament that year. The number of parties ranged from about five to eight. In the analyses I only include parties that fielded candidates in at least three consecutive elections.

Each survey contained up to 30 questions assessing attitudes towards political issues. The content of the questions varied substantially between years, reflecting political reality. For the current analysis, I included the six questions that have been asked most consistently since 1987. These are: 1) "Do you agree or disagree that progress in the capital area should be decreased in order to increase prosperity in the rural regions?" 2) "Do you agree or disagree that taxes should be reduced, even though this would mean that public services would have to be cut, e.g. in health care, education, or social security - or are you indifferent on this question?" 3) "Do you agree or disagree that restrictions on agricultural imports should be substantially relaxed - or are you indifferent on this question?" This question was omitted in the 1987, 1991, and 1995 questionnaires. 4) "Do you agree or disagree that in the next years action on environmental issues should be prioritized over attempts to increase economic growth?" $(1=$ strongly agree, $2=$ tend to agree, $3=$ no strong feeling either way, $4=$ tend to disagree, $5=$ strongly disagree). 5) "Do you think that it is desirable or undesirable, that Iceland apply for membership of the European Union?" (1 = very desirable, $2=$ rather desirable, $3=$ neutral $/$ not sure, $4=$ rather undesirable, 5 = very undesirable). This question was omitted in the 1987 and 1991 questionnaires. 6) "Regarding attempts to secure women equality with men, do you think things have gone too far, about right or not far enough?" (1 = gone much too far, 2 = gone a bit too far, 3 = about right, $4=$ need to go a bit further, $5=$ need to go much further). This question was omitted in the 1999 and 2003 questionnaires.

The demographic variables available from all years and used in the analysis are gender $(1=$ male, 2 = female), age (in years), total household income per month (five 
categories based on participants' self-reported income), and education. The assessment of education varied slightly between years. In 1987 it was based on a six-point scale (1 = compulsory schooling, $2=$ some junior college, $3=$ vocational degree, $4=$ junior college degree (matriculation; "studentsprof"), $5=$ college degree, $6=$ student). For all the other six surveys, education was categorized into seven categories based on a more detailed initial classification. The seven categories were: $1=$ compulsory schooling not completed, 2 = completed compulsory schooling, $3=$ some junior college, $4=$ junior college completed (matriculation; "studentsprof"), $5=$ vocational degree, $6=$ some college, $7=$ college degree. Note that in the 1991 and 1995 surveys the initial classification contained 14 categories whereas in 1999-2009 there were 58 categories. Finally, religiosity was assessed in three surveys, 2003, 2007, and 2009, with the item: "How religious do you perceive yourself to be?" ( $1=$ not at all, to $4=$ very religious).

\section{Results and Discussion}

\section{(Q1) Willingness to use the left-right scale}

The first question to be assessed is whether there are signs of the left-right scale having lost its meaning in people's minds. One sign of this would be a decline in the number of people who placed themselves on the scale. It should be noted, though that the Icelandic Election Study does not distinguish between "do not know" and "refuse to answer". It is therefore possible that a decline in the number of people placing themselves on the scale would indicate not its lack of meaning in people's minds, but something else, such as political apathy. Results from the analysis of overall self-placement scores from 1987 until 2009 can be seen in Table 1. These do not indicate that the scale has become meaningless over time, so differentiating between apathy and meaningless is not crucial for this analysis. On the contrary, the percentage of respondents willing to place themselves on the left-right scale has gone up over time, from a low of 75\% in 1987 to a high of $91 \%$ in 1999 , with a slight downward trend towards $84.8 \%$ in 2009 . It remains to be seen in the 2013 survey whether the low response rate in 2009 can be attributed mostly to the political upheaval following the economic collapse or whether this is a new trend.

Table 1. Left-right self-placement from 1987-2009, $0=$ left and $10=$ right

$\begin{array}{lccccc}\text { Year } & \mathrm{N} & \text { \% placement } & \text { \% picking } 5^{*} & \text { Mean } & \text { St.dev } \\ 1987 & 1745 & 78.20 & 28.5 & 5.40 & 2.40 \\ 1991 & 1491 & 75.00 & 27.8 & 5.37 & 2.36 \\ 1995 & 1721 & 79.70 & 30.8 & 5.51 & 2.13 \\ 1999 & 1631 & 91.00 & 31.0 & 5.56 & 2.32 \\ 2003 & 1446 & 90.00 & 28.5 & 5.41 & 2.20 \\ 2007 & 1595 & 87.30 & 26.2 & 5.50 & 2.13 \\ 2009 & 1385 & 84.80 & 28.1 & 5.15 & 2.10\end{array}$

*Out of people who place themselves on the scale. 


\section{(Q2) Do people increasingly choose the middle?}

Average left-right self-placement remained remarkably stable from 1987 until 2007, ranging from 5.37 to 5.56 on the eleven-point $0-10$ scale. This indicates that on average, Icelanders consider themselves to be slightly right of centre. In 2009, six months after the economic collapse, there was a noticeable change to the left, as the mean dropped to 5.15. An independent-samples t-test confirms this to be a significant $\operatorname{drop}(t(2566)=4.18, p<0.01)$.

It is possible, however, that the left-right distinction has lost meaning in another sense. People may feel that the extremities of the left and right belong to the past and that ideas and policies have reached a happy middle-ground position. In that case, although people can use the left-right scale, and will do so when asked by survey companies, we would expect a noticeably increased tendency to use the middle of the scale, or 5 . As can be seen from Table 1, this is not the case, as the percentage of people choosing 5 has remained very stable across time, ranging from $26.2 \%$ to $30.8 \%$, with an average of $28.7 \%$.

\section{(Q3a) Has political polarization taken place?}

In stark contrast to the claim that the left-right scale does not matter anymore is the notion that the electorate has become more polarized over time. As discussed in the introduction, polarization is somewhat complicated and can be viewed as real or representing sorting of subgroups. In this paper, the focus is not to estimate an absolute level of polarization, but rather to examine whether people on the left and right seem to have been moving further from each other over time, or closer together, or to have stayed relatively stable. To test for polarization in the way Icelanders use the left-right scale, standard deviations for the left-right placement were compared across the seven surveys. In the light of the highly stable mean left-right placement over time, an increased standard deviation would reflect an increased spread in political opinions, and probably be indicative of polarization, whereas a reduction in standard deviation would reflect more clustering around the middle. Increased standard deviation is thus a necessary condition for polarization to have occurred on the leftright scale, but not a sufficient one. As can be seen in the last column of Table 1, the standard deviation has remained stable across time, ranging from 2.10 to 2.40. Thus, overall, there is no sign of real polarization in Icelanders' left-right self-placement. The consistency in the distribution becomes even more apparent when graphed. Figure 1 shows bar graphs of the distribution for left-right self-placement for all seven surveys. As is immediately apparent, all distributions are highly similar. Around $26 \%-31 \%$ pick the number five and a very low percentage of respondents place themselves at the two most extreme categories on the left or right. 
Figure 1. The distribution of left-right self-placement from 1987-2009
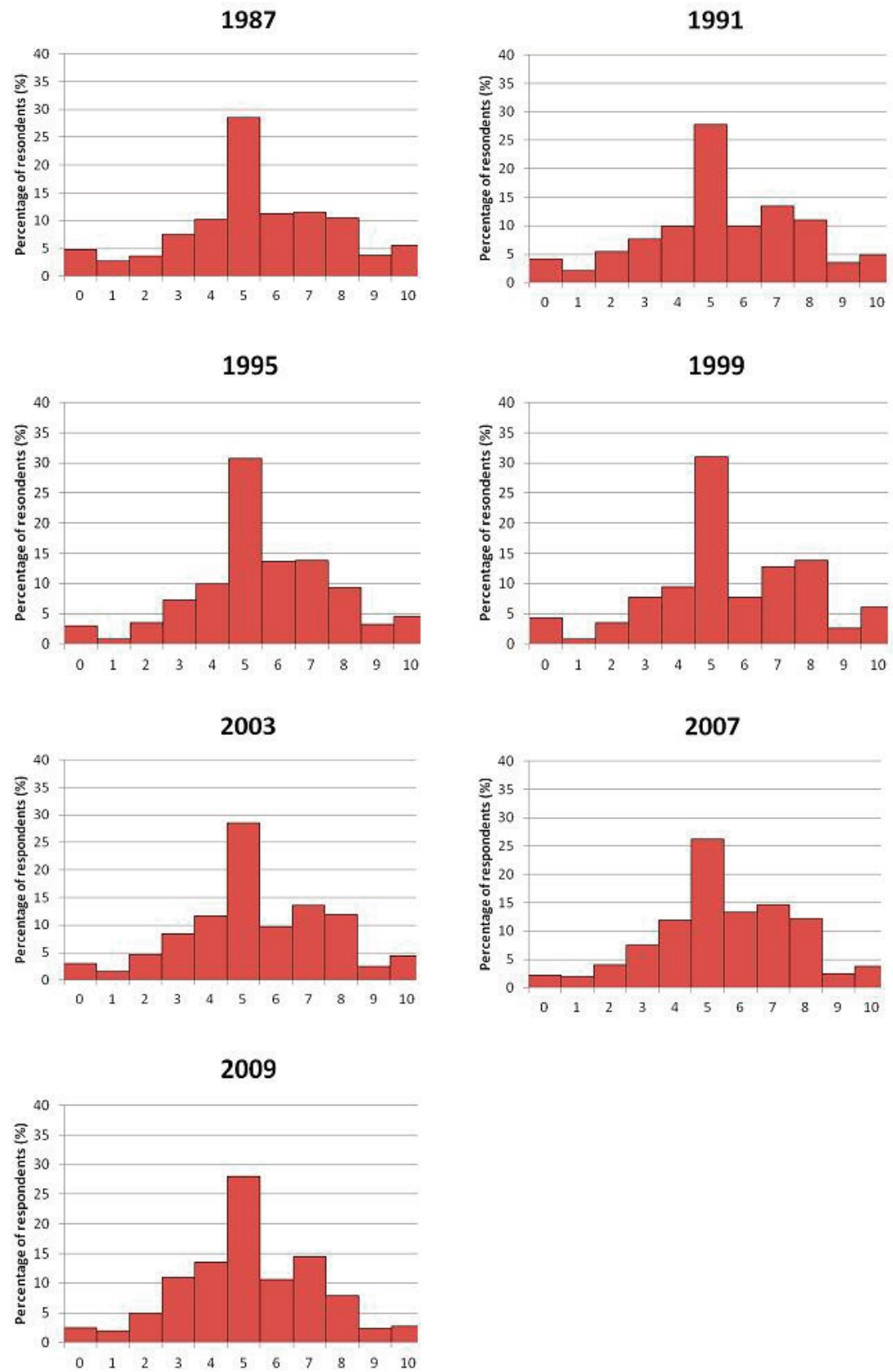


\section{(Q3b) Has political sorting taken place?}

Even though results so far do not indicate political polarization, it is possible that the aggregate results of left-right placement mask political movements by political parties, or what has been called sorting. It is conceivable that while voters for some parties are moving towards the left, others are moving more towards the centre, etc. Figure 2 graphs left-right self-placement across time for voters for all main political parties. We see that the self-placement of voters for the Independence Party, the Progressive Party, the Women's Alliance, and the Left-Greens have remained quite stable across time. The two shifts in the graph are both in left-wing parties, the People's Alliance and the Social Democratic Alliance, shifting further to the right across time by close to 1.0 points.

Figure 2. Left-right self-placement from 1987-2009 for voters for the main political parties. The numbers in parentheses indicate the range of percentage of votes each party has received in general elections from 1987-2009

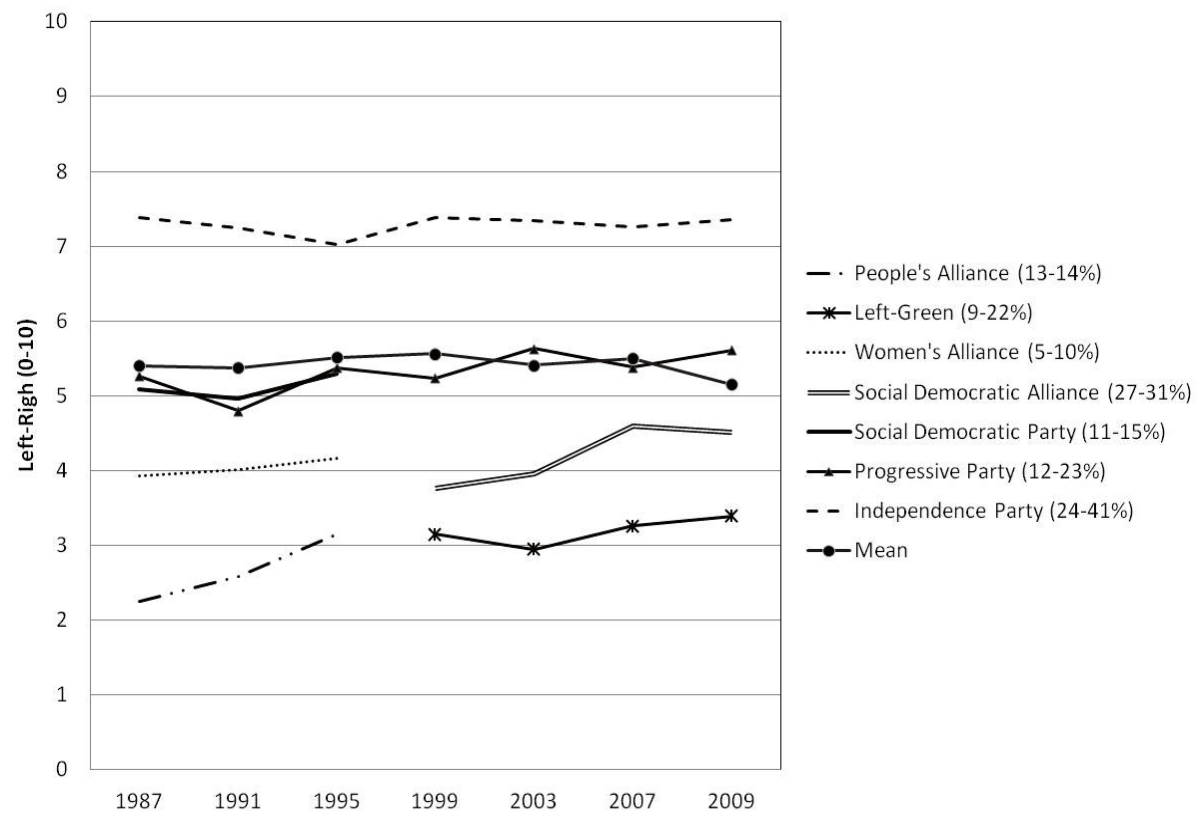

The political landscape to emerge in Figure 2 is overall in line with the general perception of the Icelandic political landscape (Kristinsson, 2007). The Independence Party is consistently furthest to the right, followed by the Progressive Party, then the Social Democratic Alliance (SDA), and the Left-Greens being the leftmost party. The rightward shift of the SDA could be explained by the most left-leaning voters for the party in 1999 and 2003 having moved to the Left-Greens in later years. At the same time, business oriented right-wing-leaning voters from the Independence Party may 
have moved to the SDA, mostly because of the latter party's pro-European Union stance.

At first glance it may seem surprising that the overall average has been shifting leftward in recent years despite the fact that the SDA, usually the second largest party in Iceland, has moved to the right, and in no case have voters of other parties party moved to the left. This can be explained by taking into account that the number of voters behind each party vary between surveys. In the year 2009, for example, the Independence Part was widely blamed for playing a crucial role in the economic collapse and therefore it took a dramatic hit in the elections, going from $36.6 \%$ to $23.7 \%$. That year, the Left-Greens went from $14.3 \%$ to $21.7 \%$. Thus, although the self-placement of voters who remain loyal to their party has not changed, those who leave may assimilate their views slightly to that of their new party.

Another possible take on polarization is subgroup sorting on left-right selfplacement by demographic variables. An increased correlation over time between leftright placement and a particular demographic variable would be a sign of such sorting. Sorting can be the result of parties to the left or right specifically targeting certain demographic groups in their policy position. An example would be a rightwing party emphasizing the importance of religious and traditional values, or a leftwing party emphasizing accessible child-care, maternity leave and other issues typically important to women. Table 2 graphs the bivariate correlation between left-right placement and gender, family income, education and religiosity. Only gender and family income show a consistent significant correlation with left-right. Men are more likely to be further to the right than women, and higher family income is related to more right-leaning self-placement. There has not, however, been a noticeable change over time in the correlation coefficients for gender, income, nor any of the other demographic variables.

Table 2. Bivariate correlation (Pearson's $r$ ) between left-right self-placement and demographic variables

$\begin{array}{lccccccc} & 1987 & 1991 & 1995 & 1999 & 2003 & 2007 & 2009 \\ \text { Gender } & -0.06^{*} & -0.15^{*} & -0.01 & -0.10^{* *} & -0.10^{* *} & -0.16^{* *} & -0.13^{* *} \\ \text { Age } & 0.00 & -0.04 & -0.05^{*} & -0.01 & 0.00 & 0.01 & -0.02 \\ \text { Family income } & 0.11^{* *} & 0.11^{* *} & 0.06^{*} & 0.12^{* *} & 0.08^{* *} & 0.14^{* *} & 0.08^{*} \\ \text { Education } & -0.07^{*} & 0.038 & 0.00 & 0.05^{*} & 0.01 & 0.02 & 0.04 \\ \text { Religiosity } & & & & & 0.08^{* *} & 0.15^{* *} & 0.05^{*} \mathrm{p}< \\ & & & & & & & \end{array}$

Left-right self-placement $(0=$ left to $10=$ right), Gender $(1=$ male, $2=$ female), Age in years, Family income (five equal categories, lowest through highest), Education (seven categories, except in 1987 when there were six), religiosity $(1=$ not at all, $4=$ very religious $)$. 


\section{(Q4) Signs of false polarization?}

Although there has not been a real polarization in the way Icelandic voters perceive their left-right stance, polarization can also be falsely perceived to have taken place. As was discussed in the introduction, there might be an overall sense that a particular political party has been moving very far right or left, even though its own voters have not been changing.

In addition to placing themselves on the left-right scale, participants were asked to place all political parties running for election that year on that same left-right scale. Figures 3 to 6 show the results for the five most prominent parties from 1987 until 2009. Again, we do not see big or consistent changes in the way the parties are perceived by their own voters or by the voters for other parties. All voters perceive the Independence Party as having moved to the left by just over half a point over time. As a matter of fact, there seems to be remarkable consistency between voters for all parties in how they perceive the political stance of both their own and other parties.

Two classic signs of polarization are, however, evident in this analysis. First, although the Independence Party is seen as standing further to the right by voters for all parties than the self-placement of its own voters indicates, voters for left-wing parties are especially likely to place the Independence Party far to the right. This type of perceived polarization was expected to hold true for the leftmost party as well, the People's Alliance and later the Left-Greens. As can be seen from Figure 3, this does not seem to be the case, as voters for the Independence Party and the People's Alliance/Left-Greens show a remarkable level of alignment in their assessment. Second, the parties furthest to the left and right show the least amount of alignment between how the voters for those parties perceive their own left-right political orientation and how they perceive their own party's orientation. This is a telltale sign of perceiving oneself as more reasonable and rational than most other people (Pronin, 2007). Voters for the People's Alliance/Left-Green Party, see themselves on average about 1.0 point closer to the middle than they perceive the party stance. The flipside picture emerges for the Independence Party. There the average self-placement of its voters has hovered at just under 7.5 , while at the same time they have viewed their party as being considerably further to the right, at about 8 to 8.5 , although the discrepancy seems to be diminishing over time. The two parties closer to the middle, the SDA and the Progressive Party, both show a very close alignment between voters' self-perception and their perception of their own parties. 


\section{STJÓRNSÝSLA}

Figure 3. Perceptions of the People's Alliance/Left-Greens on the left-right scale by voters for all parties. The graph also depicts self-placement of People's Alliance/Left-Green voters
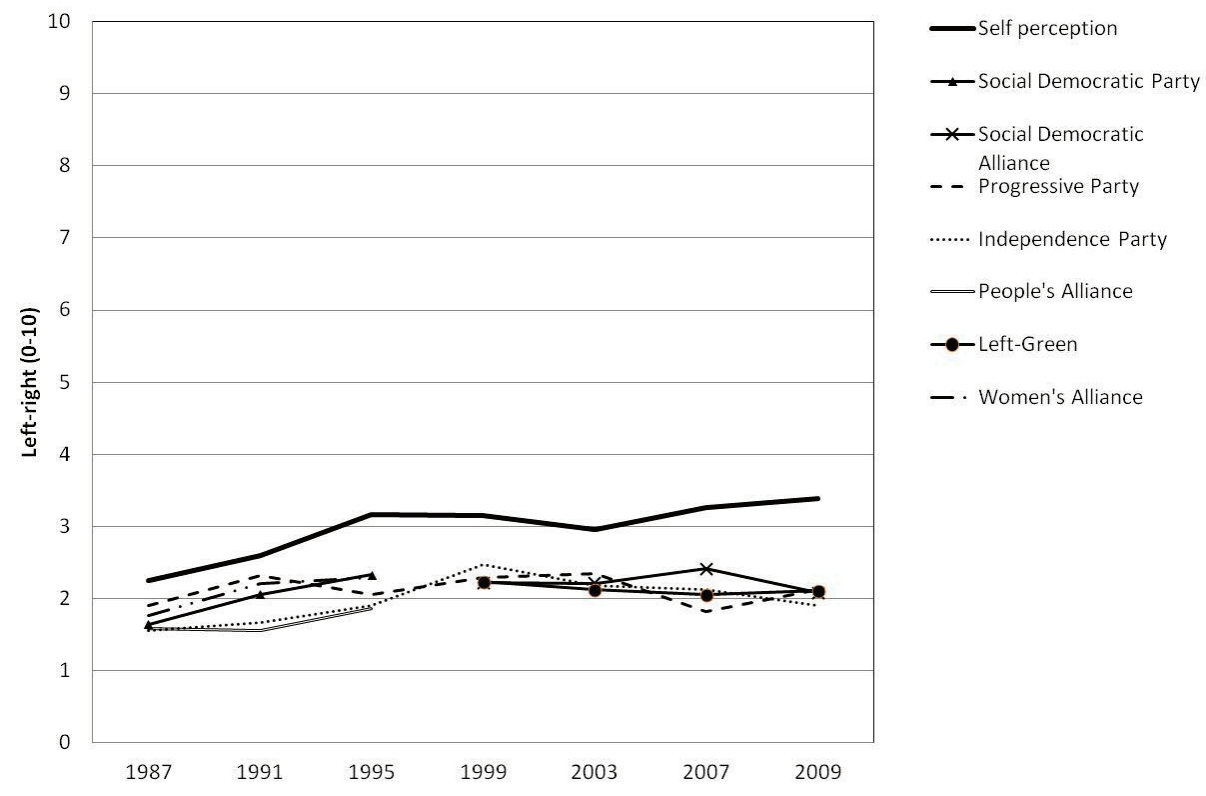

Figure 4. Perceptions of the Social Democratic Alliance on the left-right scale by voters for all parties. The graph also depicts self-placement of SDA voters

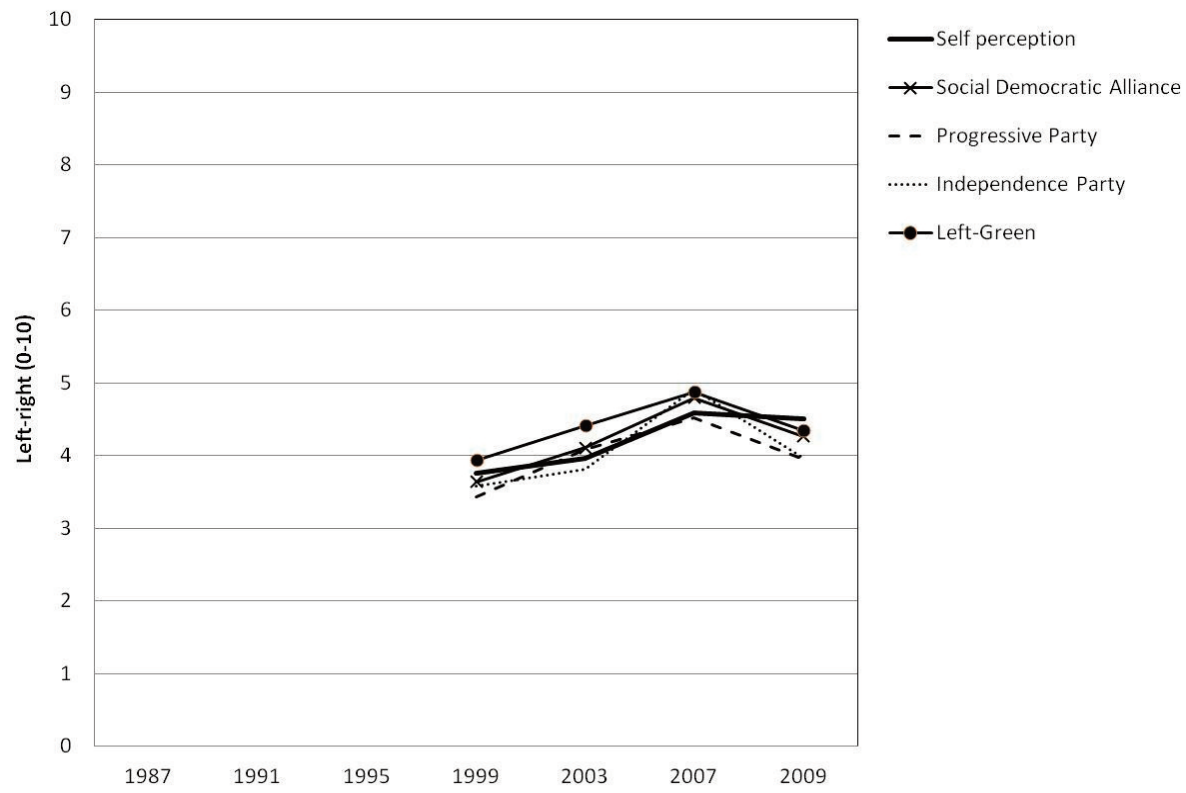


Left-right dimension in the minds of Icelandic

voters 1987-2009

Hulda Pórisdóttir

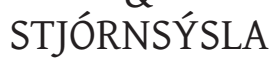

Figure 5. Perceptions of the Progressive Party on the left-right scale by voters for all parties. The graph also depicts self-placement of Progressive Party voters

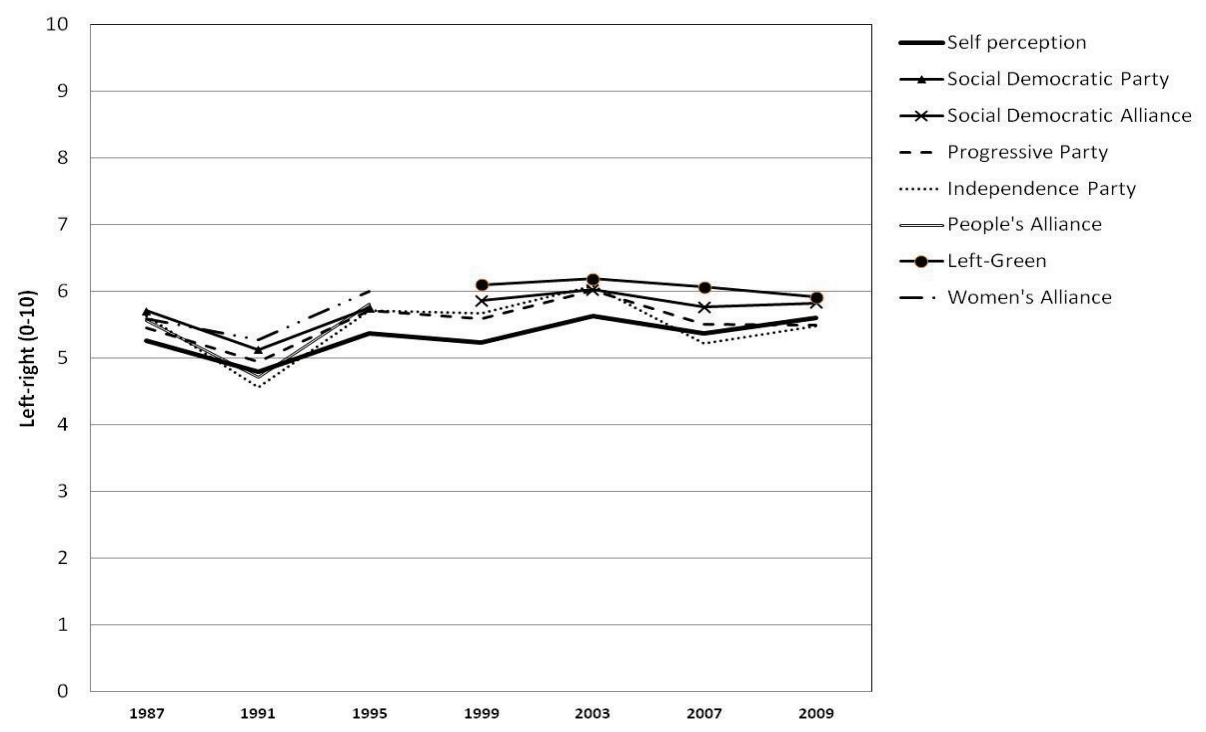

Figure 6. Perceptions of the Independence Party on the left-right scale by voters for all parties. The graph also depicts self-placement of Independence Party voters

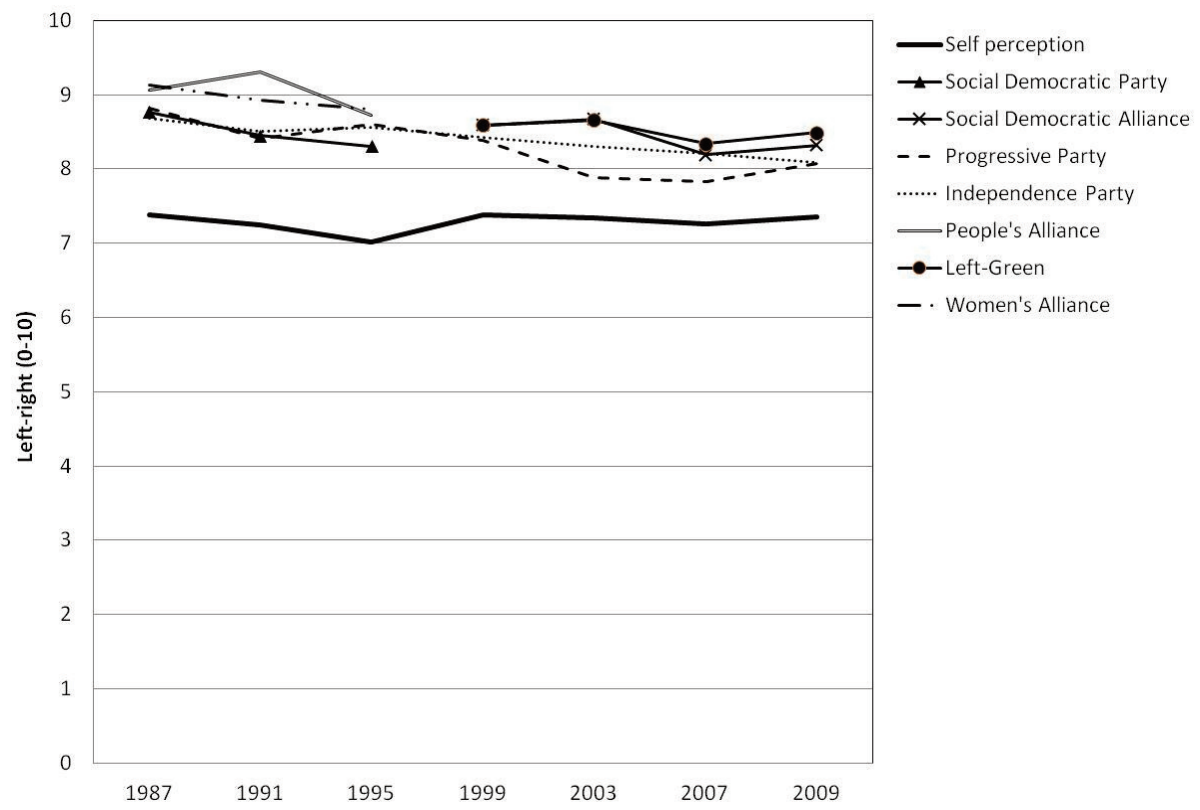


Of course, in reality, there does not have to be a close alignment between the average voter's self-placement on the left-right scale and his or her placement of the party's true policies or its political leaders, but such a misalignment should be viewed with concern by party leaders. It indicates either an image problem a miscommunication of its political stance, or a true misalignment between the way it pursues politics and where its voters stand.

\section{(Q5) Left-right self-placement and attitudes on political issues}

An analysis of how attitudes toward political issues relate to the left-right scale over time can give us an insight into the psychology of political orientation. Does the overall lack of change in left-right self-placement across time, as documented so far, mask a real change in attitudes towards issues? That is, has the entire electorate perhaps shifted its position on the political issues and has what people perceive as left, right, and centre on the scale changed accordingly? An analysis of the six questions on political attitudes asked most consistently across all seven studies can be seen in Figure $7 \mathrm{a}-7 \mathrm{f}$. As is noticeable from examining the black bars portraying the means for all six issues, only one shows a consistent change in overall attitudes over time. This is the question on whether progress in the capital area should be decreased in order to increase prosperity in the rural regions. Over time, respondents have become somewhat less likely to answer this question in the affirmative. All other items show occasional fluctuations between surveys, but no trend is discernible.

An examination of the correlation between each issue and the left-right scale over time shows whether that issue seems be contributing more or less to ideological selfplacement as the years go by. If the correlation between political issues and left-right placement is on the rise, it signifies a potential polarizing issue. The correlations are plotted as a line on the secondary axis in Figure 7 . We see that as a rule, attitudes towards the environment have the strongest relationship with the left-right scale, hovering around $\mathrm{r}=0.20$. Other issues have either a lower or an inconsistent correlation. More importantly, we do not see for any of the six items that the relationship with left-right placement has been growing stronger over time. On the contrary, for attitudes towards EU membership and restrictions on agricultural imports, the relationship has been weakening. It is important to reiterate that it is not the scope of this paper to examine which political issues play the biggest role in determining people's left-right self-placement. Each survey contained many more attitude items that tap into the political climate at the time than are used here. The six items used in this analysis were not chosen because they were believed to play the biggest role in determining left-right stance, but because they were the items most consistently asked throughout all seven surveys. Although the items cover a fairly broad spectrum of attitudes, they may or may not include items that most sharply divide the electorate into left and right at any given time. Finally, it has to be made clear that none of the attitude questions used in this study tap into real policy views; they do not ask, for example, how much income tax people think is appropriate, or which particular measures aimed at obtaining gender equality they favour or oppose. This analysis cannot, 
therefore, determine whether people's perception of what constitutes high or low taxes has changed towards the left, right, or centre. What we do know is that these issues have not contributed to a changed political landscape.

Figure 7. Attitudes towards six political issues across time. The black bars show averages, the grey line Pearson's correlation with left-right self-placement

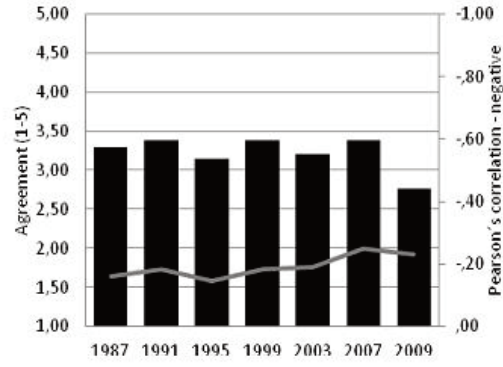

7a. Environmental issues should be prioritized over economic growth.

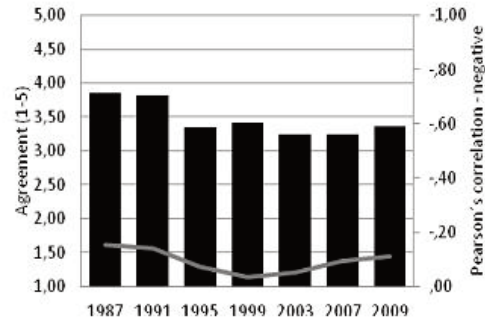

7c. Decrease progress in capital area to increase prosperity in rural areas.

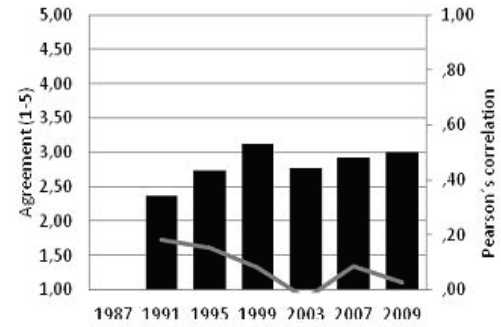

7e. EU application is desirable.

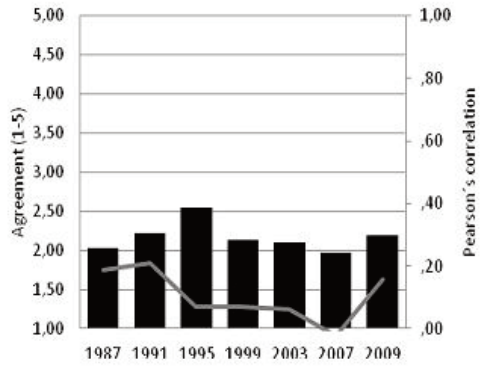

$7 \mathrm{~b}$. Taxes should be reduced

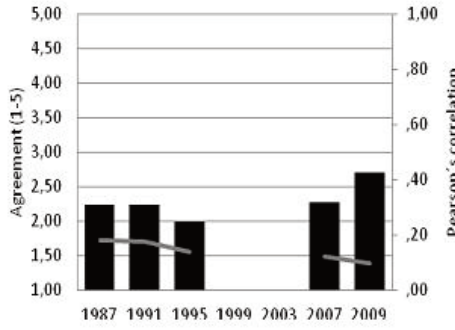

$7 \mathrm{~d}$. Attempts to ensure gender equality gone too far.

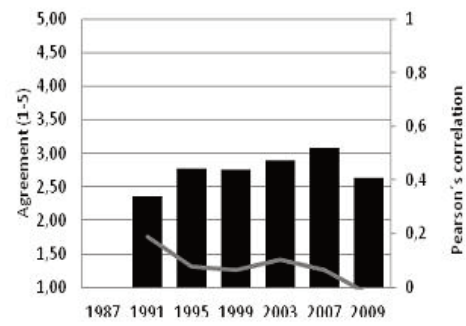

7f. Ease restrictions on agricultural imports

7a. Environmental issues should be prioritized over economic growth. 7b. Taxes should be reduced. 7c. Decrease progress in capital area to increase prosperity in rural areas $\mathbf{7 d}$. Attempts to ensure gender equality gone too far. 7e. EU application is desirable. 7f. Ease restrictions on agricultural imports 


\section{Conclusion}

This study has examined the left-right political dimension in the minds of Icelandic voters from 1987 until 2009 using the Icelandic National Election Studies. The overarching picture to emerge is one of a stable, well-defined, left-right political landscape in the minds of Icelandic voters. The vast majority of respondents, between $75 \%$ and $91 \%$, were willing to place themselves on the left-right scale and the percentage doing so has gone up over the years, albeit with a slight dip in the last two elections. The overall self-placement by Icelandic voters has been just right of centre, or about 5.5 on a scale from zero to ten.

Although Icelandic voters seem to understand and find the left-right scale meaningful, the electorate does not come across as very polarized. About $28 \%$ of respondents place themselves at the middle, with a steady tail-off to the left and right. Very few respondents place themselves in the two outermost categories on the left or right. Polarization or sorting is not rampant between social groups or political parties as correlations between left-right self-placement and several demographic variables is low to non-existent. Polarization has, in any case, not been on the rise among Icelandic voters from 1987 to 2009. This is evident from two facts. First, the standard deviation of the distribution for left-right self-placement has remained almost unchanged during the period. Second, self-placement of voters for all parties has remained mostly unchanged over time, with only a slight right-leaning shift by the voters for two left-wing parties. False polarization is not widespread either, because there was a close alignment between how voters for a particular party perceived its left-right stance and how voters for other parties perceived it. This was true for all parties, left, right and centre. Voters for the parties furthest left and right placed their political orientation closer to the middle than they placed their party, a sign of the human tendency to consider one own more moderate and reasonable in opinion compared to others.

Lastly, the contextual nature of the left-right dimension was examined by looking at the relationship over time between attitudes on six political issues and left-right self-placement. Results showed stable attitudes over time on five out of six issues, as well as stable correlation with the left-right self-placement. This further supports the picture that emerges from the analysis of overall left-right self-placement, i.e., one of a stable political landscape. It does not seem to be the case, at least not for the six items used in these analyses, that political attitudes have been moving either to the left or to the right, and that people have adjusted their sense of the left-right scale accordingly.

\section{Notes}

1 I would like to thank Ólafur Harðarson for his pioneering work on the Icelandic National Election Studies. Thanks are also due to him and to Eva Heiða Önnudóttir, Helga Lára Haarde, Karen Erla Karólínudóttir and the staff at the Social Science Research Institute at the University of Iceland for making the data accessible and available online. Finally, I would like to thank Karen Erla for assistance during the writing of this article. 


\section{References}

Abramowitz, A. I., \& Saunders, K. L. (2008). "Is polarization a myth?” Journal of Politics, 70, 542-555.

Abramowitz, A. I., \& Saunders, K. L. (2005). "Why can't we all just get along? The reality of a polarized America." The Forum, 3, 1-22.

Bell, D. (1960). The end of ideology. Glencoe, IL: Free Press.

Bobbio, N. (1996). Left and right. Cambridge, UK: Polity Press.

Burke E. 1790/1987. Reflections on the Revolution in France, and on the Proceedings in Certain Societies in London Relative to that Event, ed. JGA Pocock. Indianapolis, IN: Hackett Publishing Company

Conover, P.J. \& Feldman, S. (1981). The origin and meaning of liberal/conservative self identification. American Journal of Political Science, 25, 617-645

Converse P.E. (1964). The nature of belief systems in mass publics. In D. E. Apter (Ed.), Ideology and discontent (pp. 206-261). New York: Free Press.

Dimdins, G. and Montgomery, H. (2003). The false polarization effect in explanations of attitudinal behavior. Current Research in Social Psychology, 8, 275-302.

Feldman, S. (1988). Structure and consistency in public opinion: The role of core beliefs and values. American Journal of Political Science, 32, 416-440.

Feldman, S. (2003). Values, ideology, and the structure of political attitudes. In D. O. Sears, L. Huddy, \& R. Jervis (Eds.), The Oxford handbook of political psychology (pp. 477-508). New York: Oxford University Press.

Fiorina, M. P., Abrams, S. J., \& Pope, J. (2005). Culture war? Pearson Education.

Fuchs, D., \& Klingemann H. D. (1990). The left-right schema. In Continuities in Political Action: A Longitudinal Study of Political Orientations in Three Western Democracies, eds. M. K. Jennings, J. W. van Deth. Berlin: Walter de Gruyter.

Giddens, A. (1994). Beyond Left and Right: The Future of Radical Politics, Cambridge, Polity Press.

Greenberg, J. \& Jonas, E. (2003). Psychological motives and political orientation - the left, the right, and the rigid: Comment on Jost et al. (2003). Psychological Bulletin, 129, 376-382.

Kristinsson, G. H. (2006). Íslenska stjórnkerfið. Reykjavik: Háskólaútgáfan.

Hjörvar, Helgi (2012, April 24). Kastljós [News program]. Reykjavik, Iceland: RUV (The Icelandic National Broadcasting Service).

Huntington, S. P. (1957). Conservatism as an Ideology. The American political science review, 51(2), 454 473.

Ian Adams (2001). Political Ideology Today. Manchester: Manchester University Press, 2001.

Jennings, M. K. (1992). Ideological thinking among mass publics and political elites. Public Opinion Quarterly, 56(4), 419-441.

Jost, J. T. (2006). The end of the end of ideology. American Psychologist, 61(7), 651-670.

Jost, J. T., Federico, C. M., \& Napier, J. L. (2009). Political ideology: Its structure, functions, and elective affinities. Annual review of psychology, 60, 307-337.

Jost, J.T., Glaser, J., Kruglanski, A.W., \& Sulloway, F. (2003a). Political conservatism as motivated social cognition. Psychological Bulletin, 129, 339-375.

Jost, J.T., Glaser, J., Kruglanski, A.W., \& Sulloway, F. (2003b). Exceptions that prove the rule: Using a theory of motivated social cognition to account for ideological incongruities and political anomalies. Psychological Bulletin, 129, 383-393.

Kerlinger, F. N. (1984). Liberalism and conservatism: The nature and structure of social attitudes. Hillsdale, NJ: Erlbaum.

Kinder, D. R. (1998). Opinion and action in the realm of politics. In The Handbook of Social Psychology, eds. D. T. Gilbert, S. T. Fiske, G. Lindzey, 2:778-867. Boston: McGraw-Hill.

Kirk, R. (1982). The conservative reader. Middlesex, England: Penguin Books.

Knight, 1999; Knight, K. (1999). Liberalism and conservatism. In J. P. Robinson, P. R. Shaver, and L. S. Wrightsman (Eds.), Measures of political attitudes (pp. 59-158). San Diego, CA: Academic Press.

Lipset, S. (1960). Political man. Garden City, NY: Doubleday. 
McCarty, N., Poole, K. T., \& Rosenthal, H. (2007). Polarized America: The Dance of Ideology and Unequal Riches. MIT Press Books.

Muller, J. Z. (2001). Conservatism: Historical aspects. In N. J. Smelser \& P. B. Baltes (Eds.), International encyclopedia of the social and behavioral sciences (pp. 2624-2628). Amsterdam: Elsevier.

Noël, A., \& Thérien, J. P. (2008). Left and right in global politics. Cambridge: Cambridge University Press.

Ólafur D. Harðarson (e.d.). The Icelandic National Election Studies .Social Sciences Research Institute, University of Iceland.

Opp, K. D., Finkel, S. E., Muller, E. N., Wolfsfeld, G., Dietz, H., \& Green, J. D. (1995). Left-Right Ideology and Collective Political Action: A Comparative Analysis of Germany, Israel, and Peru. In: C.J. Jenkings and B. Klandermans. The Politics of Social Protest: Comparative Perspectives on States and Social Movements. Minneapolis, United States: University of Minnesota Press.

Pickett, J. P. et al. (2000). The American Heritage Dictionary of the English Language (4 ${ }^{\text {th }}$ ed.). Boston: Houghton Mifflin Company.

Pressan.is (2012, February 24). Fyrrverandi pingmaður áhyggjufullur: Liggur við slagsmálum í matsal Alpingis. Retrieved November 20, 2012 from http://www.pressan.is/m/Article.aspx?catID=7\&ArtId=14062

Pronin, E. (2007). Perception and misperception of bias in human judgment. Trends in Cognitive Sciences, 11, 37-43.

Robinson, R., Keltner, D., Ward, A. and Ross, L. (1995). Actual versus assumed differences in construal: "Naïve realism" in intergroup perception and conflict. Journal of Personality and Social Pcychology, 68, 404-417.

Statistics Iceland/Hagstofa Íslands (n. d.). Results of general elections to the Althingi 1963-2009 Retrieved November 20, 2012 from Stephensen, Ólafur (2012, April 26). Af stjórnmálamenningarástandi. Fréttabladio. Retrieved November 20, 2012 from http://visir.is/af-stjornmalamenningarastandi/article/2012704269893.

Thorisdottir, H., Jost, J. T., Liviatan, I., \& Shrout, P. (2007). Psychological needs and values underlying left-right political orientation: Cross-national evidence from Eastern and Western Europe. Public Opinion Quarterly, 71, 175-203.

Valgarðsson, Viktor (2012). Íslenskir áttavitar, pýðing hægri og vinstri i íslenskum stjórnmálum. BA ritgerð, Háskóli Íslands.

Wilson, G. D. (Ed.) (1973). The psychology of conservatism. London: Academic Press. 